NASA Contractor Report 189147

\title{
Reaction Layer Formation at the Graphite/Copper-Chromium Alloy Interface
}

Sandra M. DeVincent and Gary M. Michal

Case Western Reserve University

Cleveland, Ohio

March 1992

Prepared for

Lewis Research Center

Under Cooperative Agreement NCC3-94 


\title{
REACTION LAYER FORMATION AT THE GRAPHITE/COPPER-CHROMIUM ALLOY INTERFACE
}

\author{
Sandra M. DeVincent ${ }^{*}$ and Gary M. Michal ${ }^{\dagger}$ \\ Department of Materials Science and Engineering \\ Case Western Reserve University \\ Cleveland, Ohio 44106
}

\begin{abstract}
Sessile drop tests were used to obtain information about copper-chromium alloys that suitably wet graphite. Characterizations of graphite/copper-chromium alloy interfaces subjected to elevated temperatures were conducted using scanning electron microscopy, energy dispersive spectroscopy, auger electron spectroscopy and $\mathrm{x}$-ray diffraction analyses. These analyses indicate that during sessile drop tests conducted at $1130^{\circ} \mathrm{C}$ for 1 hour, copper alloys containing greater than 0.98 at\% chromium form continuous reaction layers of approximately $10 \mu \mathrm{m}$ thickness. The reaction layers adhere to the graphite surface. The copper wets the reaction layer to form a contact angle of $60^{\circ}$ or less. X-ray diffraction results indicate that the reaction layer is chromium carbide. The kinetics of reaction layer formation were modelled in terms of bulk diffusion mechanisms. Reaction layer thickness is controlled initially by the diffusion of $\mathrm{Cr}$ out of the $\mathrm{Cu}$ alloy and later by the diffusion of $\mathrm{C}$ through chromium carbide.
\end{abstract}

\section{INTRODUCTION}

Continuous fiber reinforced graphite/copper $(\mathrm{Gr} / \mathrm{Cu})$ composites offer the potential for improved performance as high heat flux structures for elevated temperature applications requiring high thermal conductivity. These composites are candidate materials for applications such as space power radiator panels and as engine heat exchanger materials for hypersonic

\footnotetext{
* Graduate Student Intern at Lewis Research Center

$\dagger$ Associate Professor
} 
aircraft. $\mathrm{Gr} / \mathrm{Cu}$ composites made from pitch-based fibers possess a high thermal conductivity equivalent to copper. They also exhibit a high modulus of elasticity equivalent to beryllium, and moderate density similar to titanium [1].

The fabrication and performance of composite materials designed for elevated temperature applications is strongly influenced by the fiber/matrix interface. A key aspect of ceramic/metal interfaces is the ceramic/metal interfacial energy. However, often the ideal fiber/matrix combinations, based upon their mechanical and physical properties, have high interfacial energies [2]. The high interfacial energies relative to the surface energies of the fibers results in a lack of wetting between the metal and fibers. This intrinsic lack of wetting causes difficulties in production of the composites. More importantly, the lack of wetting can lead to fiber/matrix debonding and pore formation during the service life of the composites at elevated temperatures $[1]$.

\section{BACKGROUND}

To date, limited work has been conducted in the area of $\mathrm{Gr} / \mathrm{Cu}$ interfaces. Perhaps the most widely referenced studies have been those of Mortimer and Nicholas $[3,4,5]$. They reported that small additions of $\mathrm{Cr}$ reduce the contact angle formed by $\mathrm{Cu}$ on $\mathrm{HX} 30 \mathrm{Gr}$ and vitreous carbon in studies conducted in vacuum. Through metallographic examination, they found the presence of reaction products at the interfaces of the $\mathrm{Gr} / \mathrm{Cu}-\mathrm{Cr}$ alloy samples. Four types of reaction products were identified: continuous layers of uniform thickness, discontinuous layers of nearly uniform thickness, flaky layers partly detached from the carbon substrate and interfacial areas containing many small particles. The reaction product of the $\mathrm{Cu}-$ 1 at $\% \mathrm{Cr}$ alloy was continuous, and quantitatively determined to be $\mathrm{Cr}_{3} \mathrm{C}_{2}$.

For sessile drop experiments conducted under conditions where a continuous reaction layer forms, the appropriate form of the Young-Dupre equation [3] is as follows: 


$$
\gamma_{S V_{\text {carbice }}}=\gamma_{L_{\text {alloy }}} \cos \theta_{\text {cartide/alloy }}+\gamma_{S L_{\text {carbick/alloy }}}
$$

where $\gamma_{\mathrm{SV}_{\text {carbice }}}$ is the carbide/vapor interfacial energy, $\gamma_{\mathrm{LV}_{\text {alloy }}}$ is the alloy/vapor interfacial energy, $\theta_{\text {carbick/alloy }}$ is the contact angle between the carbide and the alloy and $\gamma_{\mathrm{SL}_{\text {carbidedalloy }}}$ is the carbide/alloy interfacial energy. The values for $\gamma_{\mathrm{Lv}_{\text {slloy }}}$ for $\mathrm{Cu}$-Cr alloys are not known, but are assumed to be less than or equal to that of the interfacial energy of pure $\mathrm{Cu}$ and its vapor, $\gamma_{\mathrm{LV}} \mathrm{C}_{\mathrm{Cu}}$. The value for $\gamma_{\mathrm{LV}}$ has been determined as a function of temperature [6].

Mortimer and Nicholas [5] and Ramqvist [7] have conducted sessile drop tests of $\mathrm{Cu}$ on $\mathrm{Cr}_{3} \mathrm{C}_{2}$ substrates. Both investigations measured a contact angle of 45 to $50^{\circ}$. This contrasts with nonwetting angles of approximately $140^{\circ}$ observed for pure $\mathrm{Cu}$ sessile drops on graphite substrates [3]. From their studies, Mortimer and Nicholas estimated the interfacial energy of $\mathrm{Cr}_{3} \mathrm{C}_{2}$ to its vapor to be 975 to $1070 \mathrm{~mJ} / \mathrm{m}^{2}[4,5]$.

Nogi et al. [8] have conducted similar sessile drop experiments in an $\mathrm{Ar}-5 \mathrm{H}_{2}$ atmosphere with $\mathrm{Cu}$ alloys on single crystal $\mathrm{Gr}$ substrates. They also concluded that $\mathrm{Gr}$ is wet by $\mathrm{Cu}-\mathrm{Cr}$ alloys when the $\mathrm{Cr}$ content is high enough to create a continuous reaction layer at the interface.

In this study, sessile drop tests of $\mathrm{Cu}$ alloys containing a range of $\mathrm{Cr}$ contents on $\mathrm{Gr}$ substrates were investigated to determine their wetting behavior and extent of reaction layer formation. The nature of the reaction layers formed is then discussed in terms of thermodynamic and kinetic factors influencing reaction layer formation and its implication for actual $\mathrm{Gr} / \mathrm{Cu}$ composites.

\section{EXPERIMENTAL PROCEDURE}

Extruded bar stock from vacuum induction melted $\mathrm{Cu}$ alloys containing $0.61,0.98,1.10$ and 1.22 at\% $\mathrm{Cr}$ was used for sessile drop evaluations. Tests were also run using pure $\mathrm{OFHC}$ 
$\mathrm{Cu}$ as a standard. The chemical composition of each alloy was verified through ICP emission spectroscopy and atomic absorption spectrophotometry.

Sessile drop tests were conducted at 1 atmosphere pressure in argon gas of $99.995 \%$ minimum purity. For each alloy, two to five individual tests were run on separate occasions. Commercial grade $\mathrm{H}-490 \mathrm{Gr}$ discs of $2.54 \mathrm{~cm}$ diameter were polished to a $1 \mu \mathrm{m}$ finish and placed directly on the pancake induction coil of the furnace. $\mathrm{A} \mathrm{Cu}-\mathrm{Cr}$ alloy test specimen of $1.9 \mathrm{~cm}$ diameter and $2 \mathrm{~mm}$ height was placed on top of the Gr. Temperatures were monitored using a two wavelength optical pyrometer measuring the temperature of the Gr substrate. To minimize the thermal gradient the $\mathrm{Gr}$ was surrounded by $\mathrm{Al}_{2} \mathrm{O}_{3}$ insulation. Separate tests with thermocouples indicated the thermal gradient between the $\mathrm{Gr}$ and $\mathrm{Cu}$ was $\leq 5^{\circ} \mathrm{C}$. After achieving a vacuum $<4.6 \times 10^{-3} \mathrm{~Pa}$, the furnace was back-filled with argon. This procedure was repeated to allow additional flushing of the system. The $\mathrm{Cu}-\mathrm{Cr}$ alloy and the $\mathrm{Gr}$ were simultaneously heated to the melting point of the alloy, approximately $1083^{\circ} \mathrm{C}$. The test temperature was then raised to a $50^{\circ} \mathrm{C}$ superheat and held for $3600 \mathrm{~s}$. The test was recorded on videotape while the temperature was recorded on a strip chart recorder. The contact angles were measured at $300 \mathrm{~s}$ intervals during the test using a video monitor .

Sessile drop test specimens were cross-sectioned, mounted in epoxy and polished to a $0.25 \mu \mathrm{m}$ diamond finish. The specimens were examined in the transverse direction using a JOEL 840-A scanning electron microscope (SEM). The continuity and thickness of the reaction layer of each sample were determined. Using a Kevex system with an ultra-thin window detector, energy dispersive spectroscopy (EDS) analyses were conducted. X-ray spectra of the bulk alloy, the reaction layer and bulk Gr were obtained. Additional analyses of cross sectional specimens were performed using a PHI 660 scanning auger microscope (SAM) system. Using a Philips APD 3500 diffractometer, an x-ray spectrum was obtained from the reaction layer of the $\mathrm{Gr} / \mathrm{Cu}-0.61$ at\% $\mathrm{Cr}$ sessile drop specimen in the normal to the surface 
orientation to define which chromium carbide phase initially forms. An untested surface of a Gr substrate was also analyzed for calibration purposes.

\section{RESULTS}

Sessile Drop Test

A value of $157^{\circ}$ was observed for the contact angle of pure $\mathrm{Cu}$ on $\mathrm{Gr}$. The contact angle measurements for the $\mathrm{Cu}-\mathrm{Cr}$ alloys, along with the associated interfacial energy calculations based upon equation 1, are summarized in Table I. These data were obtained at a temperature of $1130^{\circ} \mathrm{C}$. The values reported are for the equilibrium angle. Most alloys reached equilibrium within $100 \mathrm{~s}$ after melting. The interfacial energy calculations were made using values of $1279 \mathrm{~mJ} / \mathrm{m}^{2}$ [6] for $\gamma_{\mathrm{LV}_{\text {alloy }}}$ and $975 \mathrm{~mJ} / \mathrm{m}^{2}$ for $\gamma_{\mathrm{SV}_{\text {carbide }}}$ [3]. The value for $\mathrm{Cu}$ was assumed to be constant with alloying level. By increasing the amount of $\mathrm{Cr}$ addition, the contact angle of the $\mathrm{Cu}$ alloy on $\mathrm{Gr}$ can be reduced. The results correspond to those found by others $[3,4,5,7,8]$.

Table I. Gr/Cu-Cr alloy sessile drop test results.

\begin{tabular}{cccc}
\hline $\begin{array}{c}\text { Cu-alloy } \\
\text { at\%Cr }\end{array}$ & $\begin{array}{c}\text { Cu-alloy } \\
\text { O, ppm }\end{array}$ & $\begin{array}{c}\text { contact } \\
\text { angle, }\end{array}$ & $\begin{array}{c}\gamma_{\text {carbide/Cu }} \\
\mathrm{mJ} / \mathrm{m}^{2}\end{array}$ \\
\hline 0.61 & 66 & 114 & 1495 \\
0.98 & 13 & 60 & 336 \\
1.10 & 16 & 45 & 71 \\
1.22 & 11 & 41 & 10 \\
\hline
\end{tabular}


Scanning Electron Microscopy

Micrographs of each $\mathrm{Cu}-\mathrm{Cr}$ alloy were obtained using the scanning electron microscope. This was done to establish the presence of a reaction layer at the interface, and to determine its thickness and continuity. Figures 1 and 2 contain micrographs of the interfaces formed from the sessile drop tests conducted with the $\mathrm{Cu}-0.61$ and 1.22 at\% $\mathrm{Cr}$ alloys. As indicated in Figure 1, the reaction layer formed at the $\mathrm{Gr} / \mathrm{Cu}-0.61 \mathrm{at} \% \mathrm{Cr}$ alloy interface is discontinuous and approximately $1.3 \mu \mathrm{m}$ thick. The $\mathrm{Cu}$ alloy sessile drop did not adhere to the reaction layer phase and is therefore not present in the micrograph. The interfaces formed with the higher $\mathrm{Cr}$ content alloys developed continuous reaction layers of approximately $10 \mu \mathrm{m}$ thickness as represented in Figure 2. These $\mathrm{Cu}$ alloy sessile drops adhered to the reaction layer phases which formed.

Figure 3 examines the edge of the sessile drop and the growth of the reaction layer associated with the $\mathrm{Cu}-1.10 \mathrm{at} \% \mathrm{Cr}$ alloy. As indicated, the reaction layer extends along the surface of the Gr substrate approximately $100 \mu \mathrm{m}$ beyond the perimeter of the sessile drop.

Stress induced cracking occurred between the sessile drop and the reaction layer during metallographic preparation of many of the test specimens which revealed that the reaction layer formed at the $\mathrm{Gr} / \mathrm{Cu}-\mathrm{Cr}$ interface is strongly adherent to the $\mathrm{Gr}$. The separation of the $\mathrm{Cu}$ from the reaction layer at the interface of the $\mathrm{Cu}-1.22 \mathrm{at} \% \mathrm{Cr}$ sessile drop test specimen is shown in Figure 4. The micrographs clearly indicate the adherence of the reaction layer to the $\mathrm{Gr}$ substrate.

A summary of the information obtained during the SEM analyses is given in Table II. The table describes the continuity and thickness of the reaction layer, the contact angle measured via sessile drop testing and the adherence of the $\mathrm{Cu}$-Cr alloy to the $\mathrm{Gr}$ substrate. 


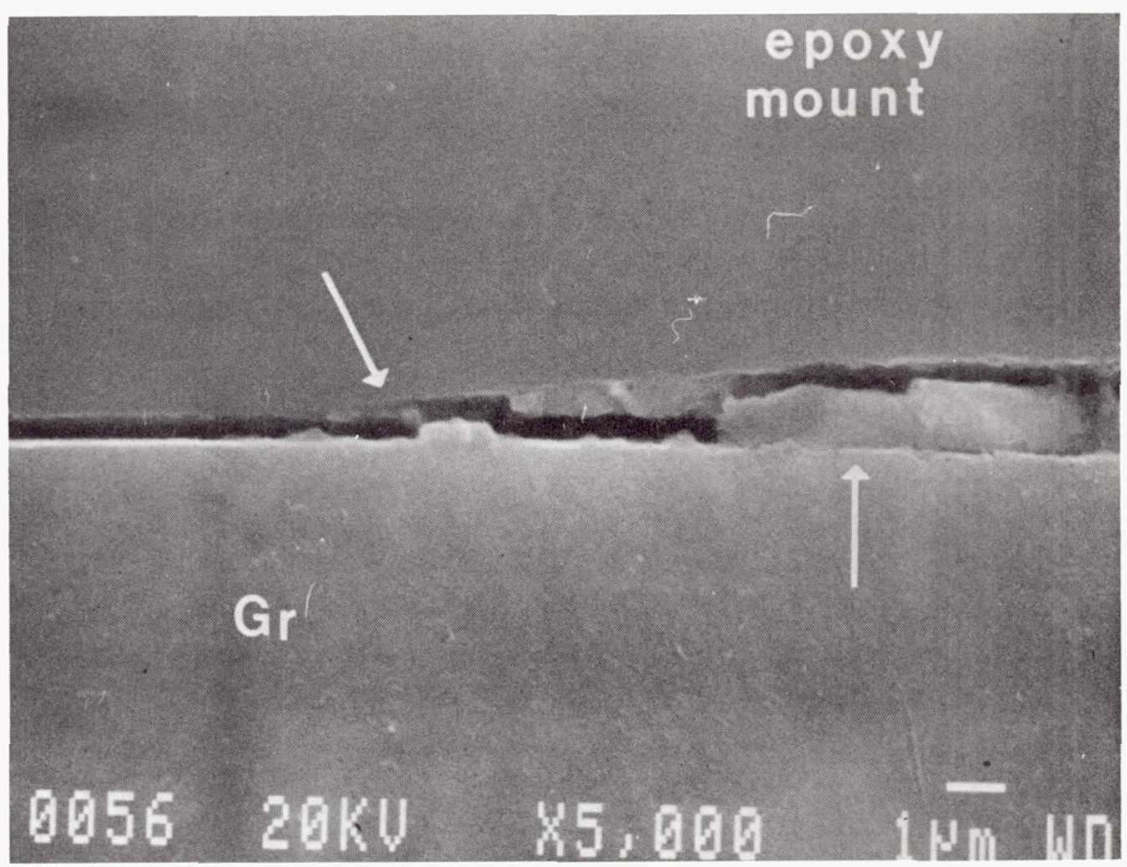

Figure 1. SEM micrograph of $\mathrm{Cu}-0.61$ at $\% \mathrm{Cr}$ sessile drop specimen. Discontinuous reaction layer on $\mathrm{Gr}$ substrate, $1.3 \mu \mathrm{m}$ thick.

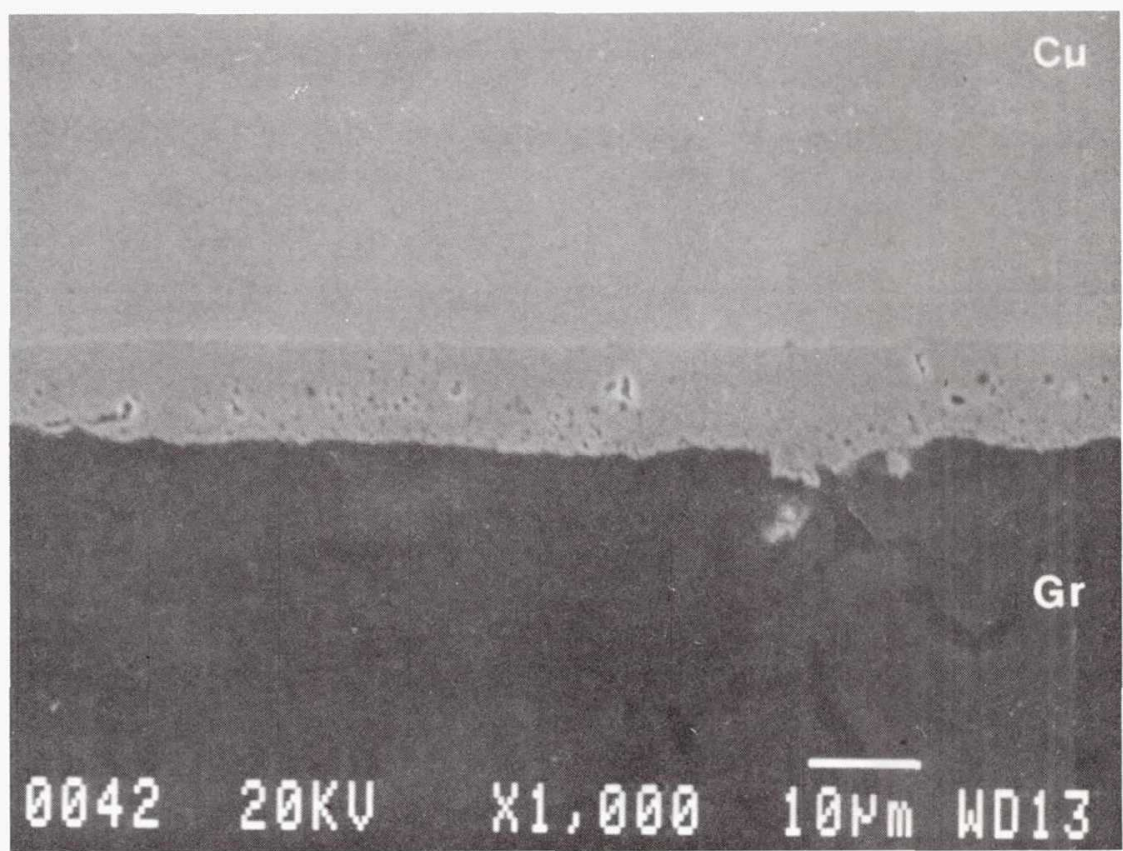

Figure 2. SEM micrograph of $\mathrm{Cu}-1.22$ at $\% \mathrm{Cr}$ sessile drop specimen. Continuous reaction layer, $10 \mu \mathrm{m}$ thick. 


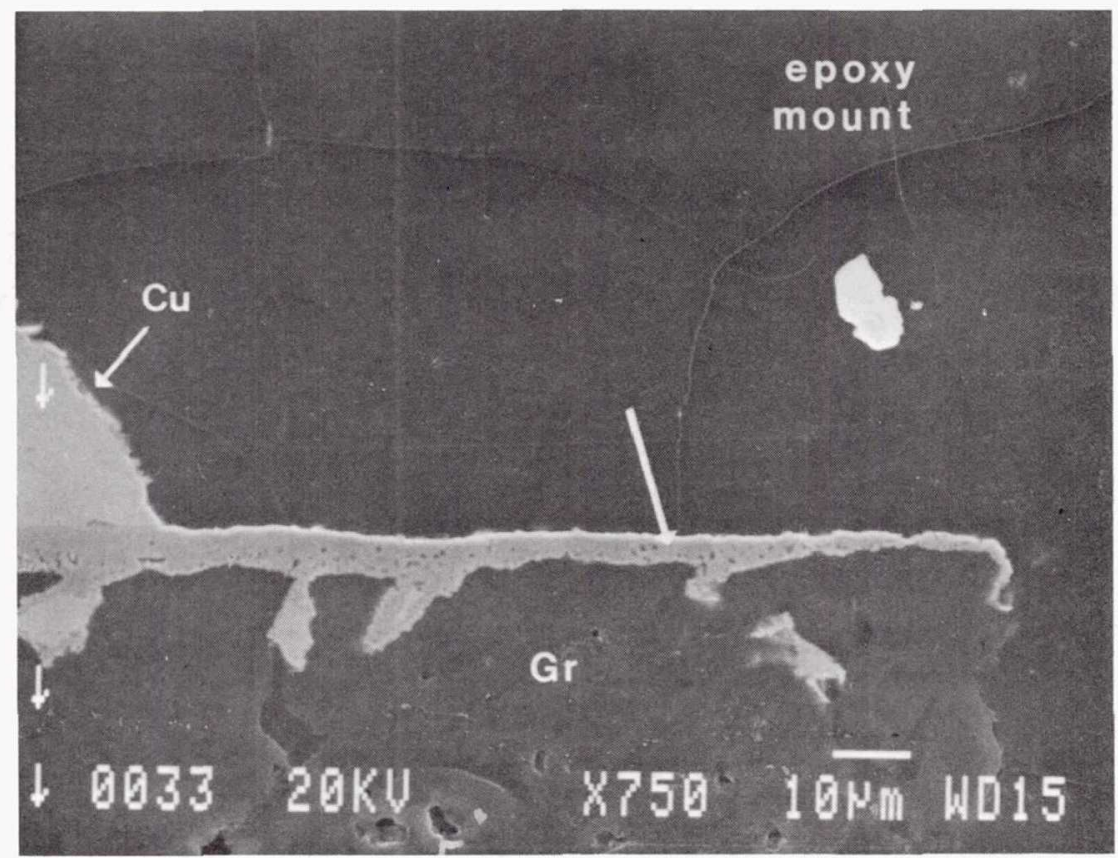

Figure 3. SEM micrograph of $\mathrm{Cu}-1.10$ at\% Cr sessile drop specimen. Reaction layer extends radially along Gr surface approximately $100 \mu \mathrm{m}$.

Table II. Summary of scanning electron microscopy analysis of $\mathrm{Cu}-\mathrm{Cr}$ alloys.

\begin{tabular}{ccccc}
\hline $\begin{array}{c}\text { Cu-alloy } \\
\text { at\% } \mathrm{Cr}\end{array}$ & $\begin{array}{c}\text { description } \\
\text { of layer }\end{array}$ & $\begin{array}{c}\text { layer } \\
\text { thickness, } \mu \mathrm{m}\end{array}$ & $\begin{array}{c}\text { contact } \\
\text { angle, }\end{array}$ & $\begin{array}{c}\text { Cu to Gr } \\
\text { adherence }\end{array}$ \\
\hline 0.61 & discontinuous & 1.3 & 114 & no \\
0.98 & continuous & 9 & 60 & yes \\
1.10 & continuous & 8 & 45 & yes \\
1.22 & continuous & 10 & 41 & yes \\
\hline
\end{tabular}



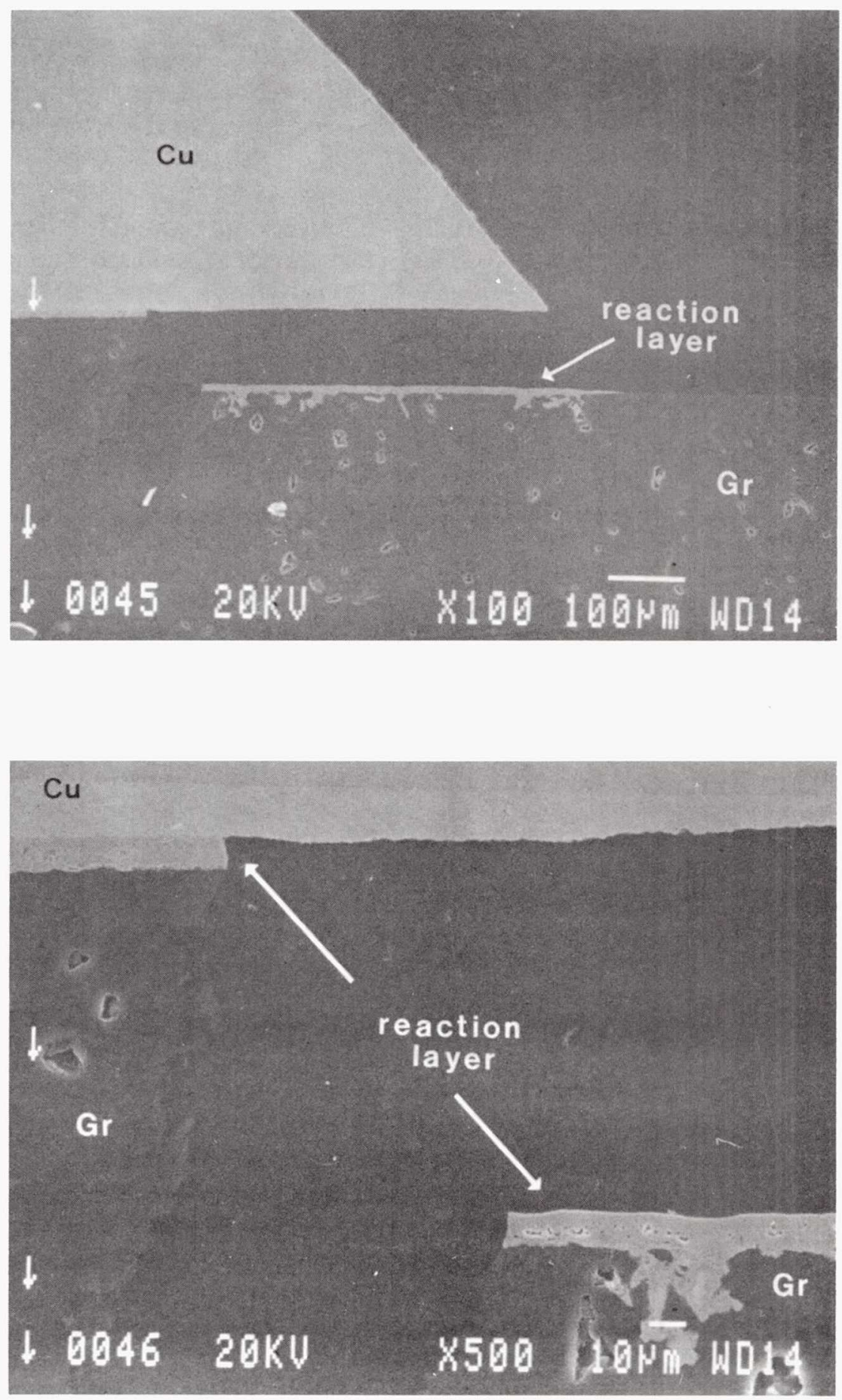

Figure 4. SEM micrograph of $\mathrm{Cu}-1.22$ at\% Cr sessile drop specimen. $\mathrm{Cu}$ is separated from $\mathrm{Gr}$ at reaction layer. (a.) Low and (b.) higher magnification. 
Energy Dispersive and Auger Electron Spectroscopy

The $\mathrm{Cu}-\mathrm{Cr}$ alloy sessile drop test specimens were characterized using EDS and AES to qualitatively identify the chemical constituents comprising the reaction layer phase. The spectra for the $\mathrm{Cu}-1.22 \mathrm{at} \% \mathrm{Cr}$ sessile drop test specimen are included in Figure 5. The bulk alloy is shown to be comprised of $\mathrm{Cu}$ with a small amount of $\mathrm{Cr}$. The reaction layer is shown to be primarily $\mathrm{Cr}$ with some $\mathrm{C}$ signal being indicated. The $\mathrm{Gr}$ bulk, as expected, shows only a very strong $\mathrm{C}$ peak. These results are representative of those found for the remaining $\mathrm{Cu}-\mathrm{Cr}$ alloys. An AES line scan approximately $60 \mu \mathrm{m}$ in length, starting in the $\mathrm{Cu}-\mathrm{Cr}$ alloy crossing the reaction layer and extending into the $\mathrm{Gr}$, is shown in Figure 6. There is a large increase in the Cr Auger peak-to-peak signal across the reaction layer. Figure 7 is an AES survey scan taken on the reaction layer after a $60 \mathrm{~s}$ sputter to remove all adventitious $\mathrm{C}$. The high concentration of $\mathrm{Cr}$ and the presence of $\mathrm{C}$ is consistent with the reaction layer being a chromium carbide phase. The loss structure on the low energy side of the $\mathrm{C}$ peak also is consistent with the $\mathrm{C}$ being bound as a carbide phase.

\section{X-Ray Diffraction}

Because the chemical composition of the reaction layer could not be quantitatively determined with sufficient accuracy via EDS or AES analyses, to define which chromium carbide phase initially formed, $\mathrm{x}$-ray diffractometry methods were employed. An x-ray diffraction scan was run on the reaction layer formed between the $\mathrm{Cu}-0.61 \mathrm{at} \% \mathrm{Cr}$ alloy and the Gr substrate. Although the reaction layer that remained adherent to the Gr substrate was discontinuous and had a maximum thickness of $1.3 \mu \mathrm{m}$, chromium carbide peaks of sufficient size and number were observed to make a unique identification. The peaks observed are listed in Table III where they are compared to those of the $\mathrm{Cr}_{3} \mathrm{C}_{2}$ phase [9]. Some of the $\mathrm{Cr}_{3} \mathrm{C}_{2}$ phase peaks were obscured due to the presence of much stronger Gr peaks generated by the substrate. 

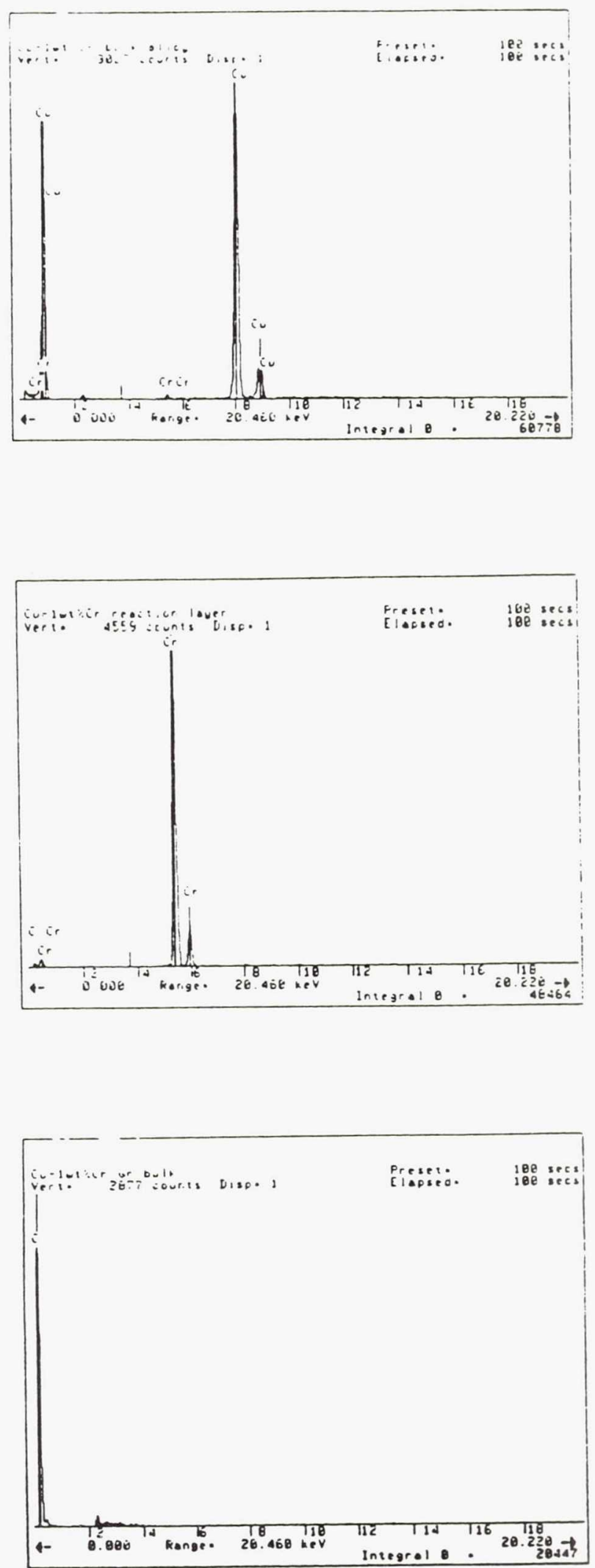

Figure 5. EDS spectra of $\mathrm{Cu}-1.22 \mathrm{at} \% \mathrm{Cr}$ sessile drop test specimen.

(a.) $\mathrm{Cu}$ alloy bulk, (b.) reaction layer and (c.) Gr bulk. 


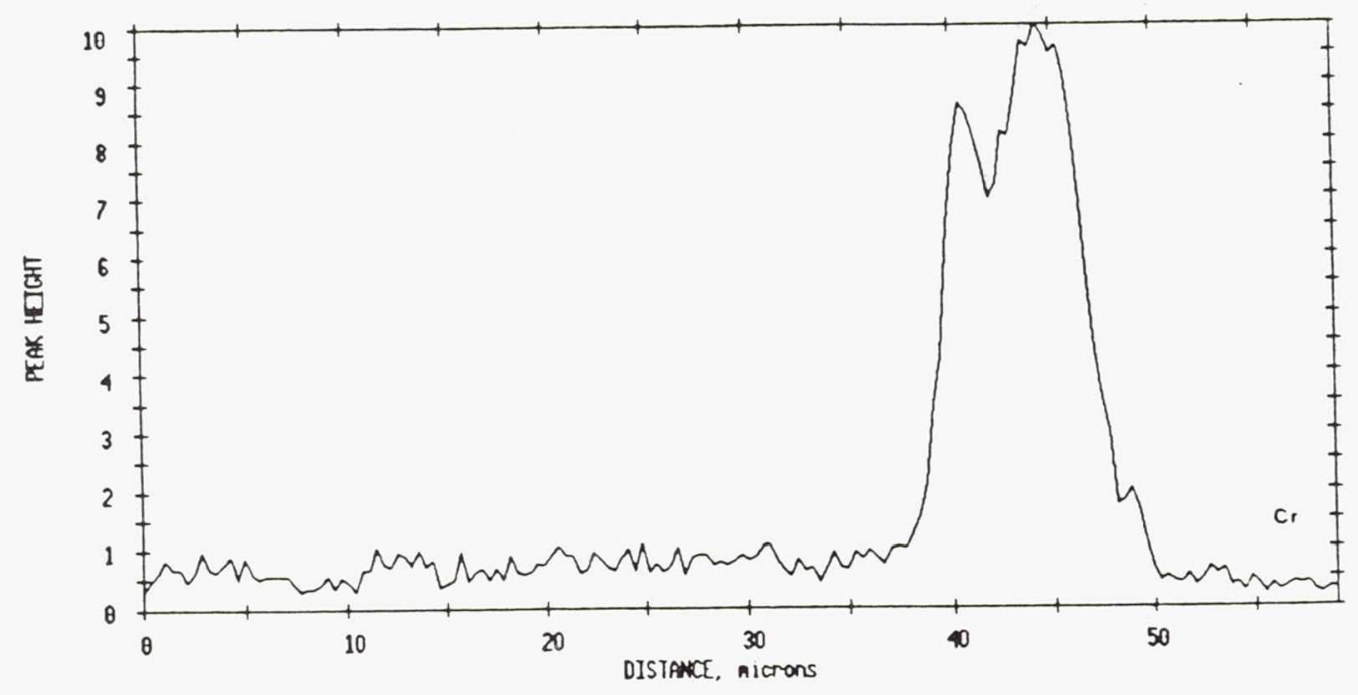

Figure 6. AES line scan of $\mathrm{Cr}$ over the interfacial region of a $\mathrm{Cu}-1.22 \mathrm{at} \% \mathrm{Cr}$ sessile drop specimen after $6 \mathrm{~s}$ sputter.

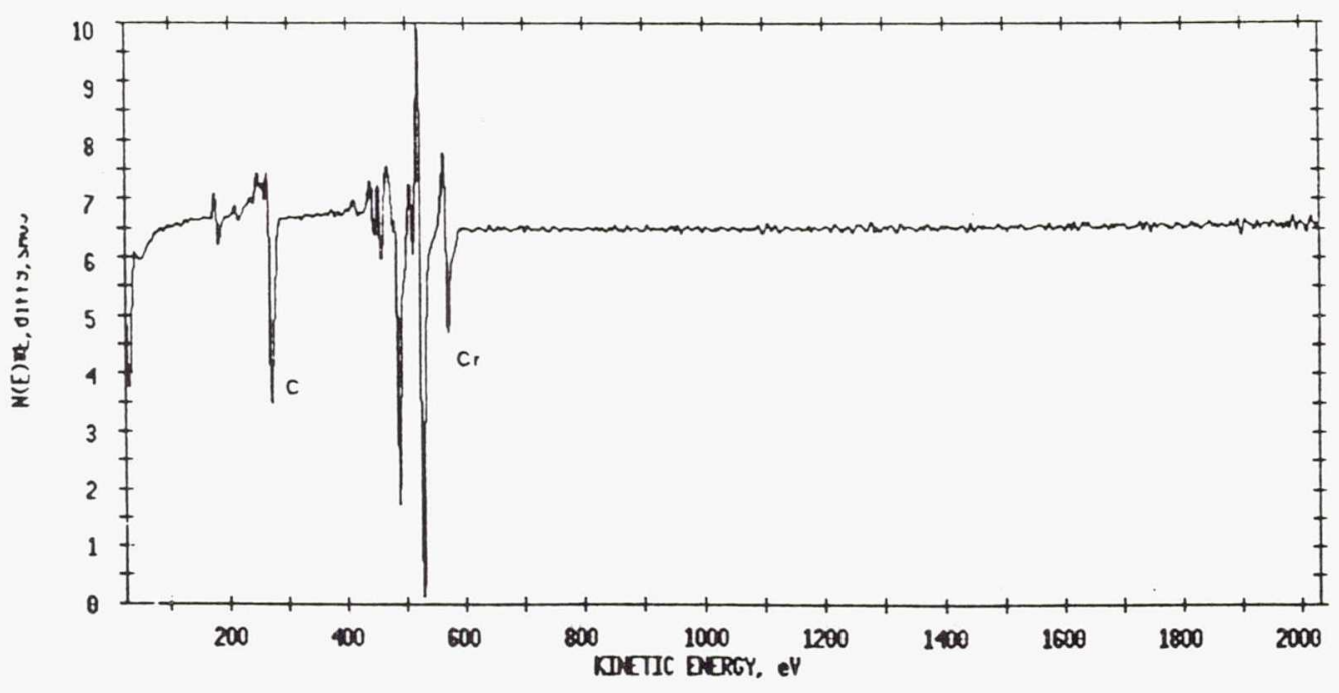

Figure 7. AES survey scan of $\mathrm{Cu}-1.22 \mathrm{at} \% \mathrm{Cr}$ reaction layer after $60 \mathrm{~s}$ sputter. 
Table III. X-ray diffraction results from the reaction layer phase formed at the $\mathrm{Gr} / \mathrm{Cu}-0.61 \mathrm{at} \% \mathrm{Cr}$ interface.

\begin{tabular}{cccc}
\hline $\begin{array}{c}\text { JCPDS 35-804 } \\
\text { Cr3C2 }\end{array}$ & $\begin{array}{c}\text { observed } \\
\text { peaks }\end{array}$ & $\begin{array}{c}\text { JCPDS 35-804 } \\
\text { Cr3 } 2\end{array}$ & $\begin{array}{c}\text { observed } \\
\text { peaks }\end{array}$ \\
\hline 4.9780 & $\dagger$ & 1.7833 & 1.80 \\
3.9830 & $\dagger$ & 1.7670 & 1.77 \\
3.1460 & $\dagger$ & 1.7567 & 1.77 \\
2.7460 & $\begin{array}{l}\dagger \\
2.5478\end{array}$ & 1.6975 & $*$ \\
2.4897 & 2.49 & 1.6602 & \\
2.4596 & 2.45 & 1.6286 & 1.57 \\
2.3063 & 2.32 & 1.5734 & 1.53 \\
2.2751 & 2.27 & 1.5302 & 1.49 \\
2.2409 & 2.25 & 1.4987 & 1.42 \\
2.1215 & $*$ & 1.4375 & 1.41 \\
2.1036 & $*$ & 1.4193 & 1.37 \\
1.9912 & 1.99 & 1.4143 & $\dagger$ \\
1.9482 & 1.94 & 1.3902 & 1.30 \\
1.9151 & 1.92 & 1.3720 & 1.29 \\
1.8934 & $*$ & 1.3273 & \\
1.8691 & 1.87 & 1.2997 & \\
1.8190 & 1.82 & 1.2812 & \\
& & & \\
\hline
\end{tabular}

$\dagger$ not observed

* graphite interference 


\section{DISCUSSION}

\section{Thermodynamics of $\mathrm{Cr}_{3} \mathrm{C}_{2}$ formation}

The degree of wetting of liquid $\mathrm{Cu}$ on the Gr substrate is shown to be affected by whether the carbide reaction layer is continuous or discontinuous as discussed by Nogi et al. [8]. Analyses of the $\mathrm{Cu}-\mathrm{Cr}$ alloy interfaces, summarized in Table II, confirmed that the best wetting is obtained when a continuous reaction layer formed. It has also been noted that only when a continuous reaction layer is formed does the $\mathrm{Cu}$ alloy test specimen adhere to the $\mathrm{Gr}$ substrate.

To start a thermodynamic assessment of the most stable chromium carbide phase, the activity of $\mathrm{Cr}$ in the liquid $\mathrm{Cu}$ sessile drop was determined. As indicated by the $\mathrm{x}$-ray diffraction results, the reaction layer phase that forms at the $\mathrm{Gr} / \mathrm{Cu}-\mathrm{Cr}$ alloy interface is $\mathrm{Cr}_{3} \mathrm{C}_{2}$. This result is consistent with thermodynamic considerations of the most stable reaction layer phase. From the $\mathrm{Cu}-\mathrm{Cr}$ phase diagram [10], at $1130^{\circ} \mathrm{C}$ the $\mathrm{Cr}$ liquid-solid transition occurs at $\mathrm{X}_{\mathrm{Cr}}=0.02$, a composition of $2 \mathrm{at} \%$. Assuming Henrian behavior, the activity coefficient of $\mathrm{Cr}$ in liquid $\mathrm{Cu}$ is found to be approximately 50. For the $\mathrm{Cu}-1.22 \mathrm{at} \% \mathrm{Cr}$ alloy used for the sessile drop experiments, the activity of $\mathrm{Cr}$ in liquid $\mathrm{Cu}$ is 0.61 . Taking the activity of $\mathrm{C}$ in the graphite substrate as unity, and that the chromium carbide phases form as pure substances, the free energy of formation for each potentially stable carbide phase can be determined [11]. The results of these calculations, based upon a gram-atom of the carbide phase, are listed in Table IV. The $\mathrm{Cr}_{3} \mathrm{C}_{2}$ phase is observed to be the most stable. Using the same thermochemical data regarding the formation of $\mathrm{Cr}_{3} \mathrm{C}_{2}$, the minimum $\mathrm{Cr}$ concentration in liquid $\mathrm{Cu}$ at $1130^{\circ} \mathrm{C}$, at which $\mathrm{Cr}_{3} \mathrm{C}_{2}$ can form, was also calculated. The $\mathrm{Cr}$ level can be reduced to 0.078 at $\%$ before equilibrium is achieved. 
Table IV. Free energies of formation of $\mathrm{Cr}$-carbide phases at $1130^{\circ} \mathrm{C}$.

Reaction $\quad \Delta \mathrm{G}, \mathrm{cal} / \mathrm{g}$-atom

$$
\begin{gathered}
\frac{3}{5} \mathrm{Cr}+\frac{2}{5} \mathrm{C}=\frac{1}{5} \mathrm{Cr}_{3} \mathrm{C}_{2} \\
\frac{7}{10} \mathrm{Cr}+\frac{3}{10} \mathrm{C}=\frac{1}{10} \mathrm{Cr}_{7} \mathrm{C}_{3} \\
\frac{23}{29} \mathrm{Cr}+\frac{6}{29} \mathrm{C}=\frac{1}{29} \mathrm{Cr}_{23} \mathrm{C}_{6}
\end{gathered}
$$

Mass balance calculations verify the feasibility of forming a reaction layer of $10 \mu \mathrm{m}$ thickness with the $\mathrm{Cu}-1.22 \mathrm{at} \% \mathrm{Cr}$ alloy. Using a radius of $9.5 \mathrm{~mm}$ and a thickness of $2.0 \mathrm{~mm}$, the volume of the $\mathrm{Cu}-\mathrm{Cr}$ sessile drop was calculated to be $570 \mathrm{~mm}^{3}$. The volume of a reaction layer of $10 \mu \mathrm{m}$ thickness is $2.9 \mathrm{~mm}^{3}$. Using a density of $6.68 \mathrm{~g} / \mathrm{cm}^{3}$ for $\mathrm{Cr}_{3} \mathrm{C}_{2}$, and assuming that the $\mathrm{Cr}$ level in the sessile drop can be reduced to 0.078 at $\%$ before the formation of $\mathrm{Cr}_{3} \mathrm{C}_{2}$ becomes thermodynamically unfavorable, a potential carbide layer volume of 8.2 $\mathrm{mm}^{3}$ can form from the $\mathrm{Cu}-1.22 \mathrm{at} \% \mathrm{Cr}$ alloy. Based on a mass balance analysis, a carbide layer approximately 2.8 times thicker than that observed could have formed.

\section{Kinetics of $\mathrm{Cr}_{3} \mathrm{C}_{2}$ formation}

The preceding discussion indicates that sufficient $\mathrm{Cr}$ was available in the liquid $\mathrm{Cu}$ sessile drops to form reaction layers consisting of $\mathrm{Cr}_{3} \mathrm{C}_{2}$ that were greater than $10 \mu \mathrm{m}$ in thickness. The fact that layers thicker than $10 \mu \mathrm{m}$ were not observed indicates that kinetic factors were influencing the reaction layer growth. Several possible mass transport mechanisms could be controlling the final thicknesses of the reaction layers that were observed. 
The first kinetic factor to be explored is the rate of diffusion of $\mathrm{Cr}$ out of the liquid $\mathrm{Cu}$.

This process can be modelled using the simplified sessile drop geometry shown in Figure 8 .

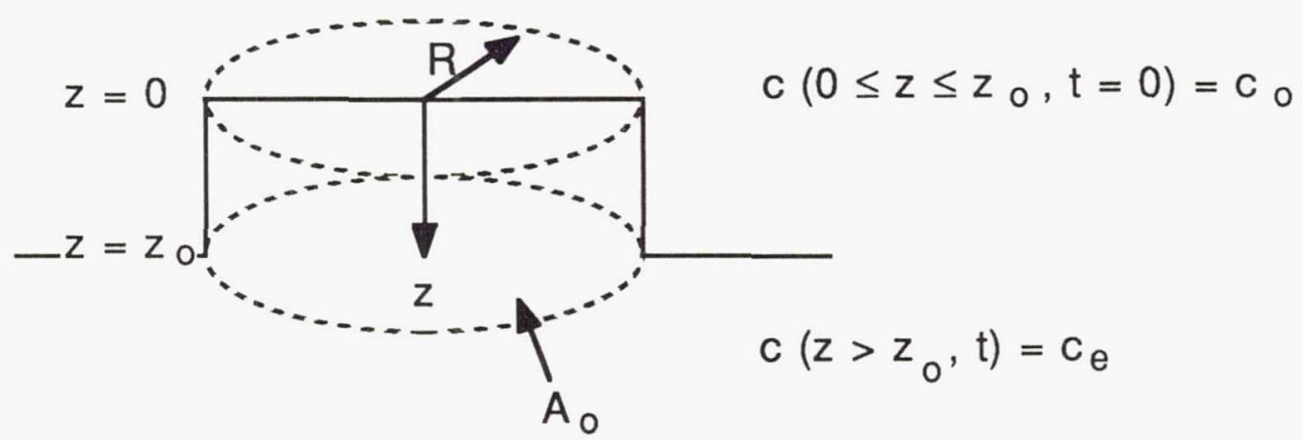

Figure 8. Simplified sessile drop geometry indicating boundary conditions for determining rate of diffusion of $\mathrm{Cr}$ out of liquid $\mathrm{Cu}$.

The following equation defines the time dependent concentration of $\mathrm{Cr}$ in the cylindrical volume shown in Figure 8, assuming solute can only exit the volume through the bottom interface [12]:

$$
c(z, t)=c_{e}+\left(c_{o}-c_{e}\right) \sum_{n=1}^{\infty} \frac{2\left(\frac{k}{D}\right) \cos \alpha_{n} z}{\left\{\left[\alpha_{n}^{2}+\left(\frac{k}{D}\right)^{2}\right] z_{o}+\left(\frac{k}{D}\right)\right\} \cos \alpha_{n} z_{o}} \exp \left(-D \alpha_{n}^{2} t\right)
$$

where $c_{\mathrm{e}}=$ concentration of $\mathrm{Cr}$ in equilibrium with $\mathrm{Cr}_{3} \mathrm{C}_{2}(0.078 \mathrm{at} \%)$

$\mathrm{c}_{\mathrm{o}}=$ initial concentration of $\mathrm{Cr}$ in the sessile drop (1.22at \%)

$\mathrm{D}=$ diffusion coefficient of $\mathrm{Cr}$ in liquid $\mathrm{Cu}$ at $1130^{\circ} \mathrm{C}[13]\left(3 \times 10-6 \mathrm{~cm}^{2} / \mathrm{s}\right)$

$\mathrm{k}=$ interfacial mass transfer coefficient between the sessile drop and the $\mathrm{Cr}_{3} \mathrm{C}_{2}$ reaction layer

$\mathrm{t}=\mathrm{time}$

and $\alpha_{\mathrm{n}}$ is defined by the roots of the following transcendental equation [12]:

$$
z_{0} \alpha_{n} \tan z_{0} \alpha_{n}=\left(\frac{k}{D}\right) z_{0}
$$


The total flux of $\mathrm{Cr}$ out of the bottom interface of the sessile drop, J, can be determined using the following equations:

$$
\begin{gathered}
J_{\text {total }}=\int_{0}^{t}-\left.A_{o} D \frac{d c}{d z}\right|_{z z_{0}} d t \\
J=A_{o}\left(c_{o}-c_{e}\right) \sum_{n=1}^{\infty} \frac{2\left(\frac{k}{D}\right) \sin \alpha_{n} z_{o}}{\alpha_{n}\left\{\left[\alpha_{n}^{2}+\left(\frac{k}{D}\right)^{2}\right] z_{0}+\left(\frac{k}{D}\right)\right\} \cos \alpha_{n} z_{o}}\left[1-\exp \left(-D \alpha_{n}^{2} t\right)\right]
\end{gathered}
$$

The total flux of $\mathrm{Cr}$ that can exit through the bottom interface of the sessile drop of the $\mathrm{Cu}$ $1.22 \mathrm{at} \% \mathrm{Cr}$ alloy is plotted as a function of time in Figure 9 for several possible values of the interfacial mass transfer coefficient. The figure shows that for interfacial mass transfer coefficient values greater than $1.5 \times 10^{-4} \mathrm{~cm} / \mathrm{s}$, interfacial transport is not greatly influencing the rate of $\mathrm{Cr}$ exiting the sessile drop. Under such conditions, more than half of the total available Cr level of $7.4 \times 10^{-4}$ moles in the sessile drop could exit in $3600 \mathrm{~s}$, the duration of the sessile drop tests conducted.

A second kinetic factor to be explored is the rate of $\mathrm{C}$ diffusion through the solid $\mathrm{Cr}_{3} \mathrm{C}_{2}$ layer at $1130^{\circ} \mathrm{C}$. This process leads to a model for parabolic growth of the $\mathrm{Cr}_{3} \mathrm{C}_{2}$ layer. The following equation defines the thickness of the reaction layer, $h$, as a function of time, $t$ [14]:

$$
\mathrm{h}=\sqrt{\frac{2\left(\mathrm{c}_{1}-\mathrm{c}_{2}\right) \mathrm{Dt}}{\mathrm{c}_{2}}}
$$

where $c_{1}=$ concentration of $\mathrm{C}$ in the $\mathrm{Cr}_{3} \mathrm{C}_{2}$ at the graphite interface

$\mathrm{c}_{2}=$ concentration of $\mathrm{C}$ in the $\mathrm{Cr}_{3} \mathrm{C}_{2}$ at the sessile drop interface

$\mathrm{D}=$ diffusion coefficient for $\mathrm{C}$ in solid $\mathrm{Cr}_{3} \mathrm{C}_{2}$ at $1130^{\circ} \mathrm{C}$ [15]

The concentration variation for $\mathrm{C}$ across the $\mathrm{Cr}_{3} \mathrm{C}_{2}$ layer at $1130^{\circ} \mathrm{C}$ is known to be very small based upon the C-Cr phase diagram [16]. For sake of calculation a value for $\left(c_{1}-c_{2}\right) / c_{2}$ of 0.01 was assumed. The diffusion coefficient for $\mathrm{C}$ in $\mathrm{Cr}_{3} \mathrm{C}_{2}$ is not known, but the activation 
energy for the diffusion coefficient has been determined to be $45 \mathrm{kcal} / \mathrm{mole} \mathrm{[15].} \mathrm{Using}$ equation 6 and a known reaction layer thickness of $10 \mu \mathrm{m}$ in $3600 \mathrm{~s}$, values of $\mathrm{D}_{\mathrm{o}}=0.14$ $\mathrm{cm}^{2} / \mathrm{s}$ and $\mathrm{D}=1.3 \times 10^{-8} \mathrm{~cm}^{2} / \mathrm{s}$ at $1130^{\circ} \mathrm{C}$ were determined.

Using equation 5 , the thickness of the $\mathrm{Cr}_{3} \mathrm{C}_{2}$ reaction layer was determined as a function of time and plotted in Figure 10. For comparison, the thickness of reaction layer that could be produced by the total flux of $\mathrm{Cr}$ out of the liquid $\mathrm{Cu}$ sessile drop, shown in Figure 9 , is also plotted in Figure 10. In this latter case, a value for the interfacial mass transfer coefficient of $1.5 \times 10^{-3} \mathrm{~cm} / \mathrm{s}$ was used. Only for the first $100 \mathrm{~s}$ of growth, up to a reaction layer thickness of approximately $1.6 \mu \mathrm{m}$, is diffusion of $\mathrm{Cr}$ out of the sessile drop controlling the rate of growth of the reaction layer. From that point onward, diffusion of $\mathrm{C}$ through the $\mathrm{Cr}_{3} \mathrm{C}_{2}$ layer controls the rate of growth.

The other interesting observation regarding the $\mathrm{Cr}_{3} \mathrm{C}_{2}$ reaction layer was its extension beyond the edge of the sessile drop. As was shown in Figure 3, the layer extended radially outward on the order of $100 \mu \mathrm{m}$ from the perimeter of the sessile drop. At $1130^{\circ} \mathrm{C}$, the equilibrium vapor pressure of liquid $\mathrm{Cu}$ is $0.145 \mathrm{~Pa}$ [17]. At such a high vapor pressure the exchange of a monolayer of atoms between the liquid $\mathrm{Cu}$ surface and the vapor phase occurs in approximately $0.001 \mathrm{~s}$. In the large bell jar chamber used for the sessile drop experiments the equilibrium vapor pressure of $\mathrm{Cu}$ was never established. So, evaporation of $\mathrm{Cu}$ was occurring throughout the experiments. The maximum evaporation rate possible would have been about 1000 atomic layers of $\mathrm{Cu}$ per second. At such an evaporation rate, considerably more than a $100 \mu \mathrm{m}$ thick layer of $\mathrm{Cu}$ could have evaporated from the surface of the sessile drop during the typically $3600 \mathrm{~s}$ hold at temperature. Thus, as the evaporation of $\mathrm{Cu}$ continued during an experiment, an increasing amount of the chromium carbide reaction layer was exposed. This led to the observation shown in Figure 3 of the reaction layer extending out from under the sessile drop at the termination of a test. 


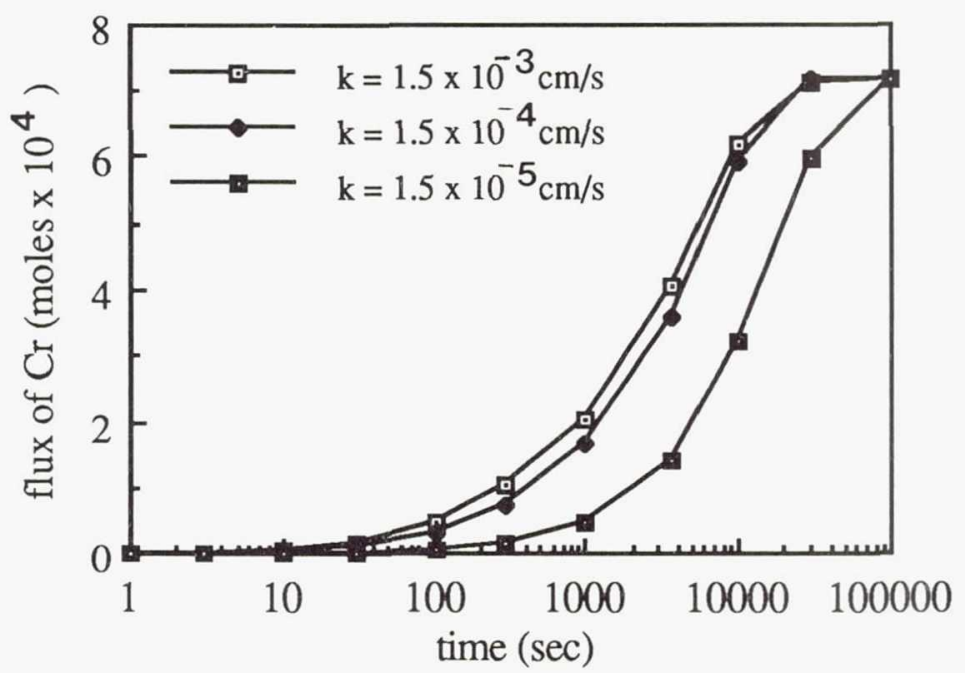

Figure 9. Flux of $\mathrm{Cr}$ out of liquid $\mathrm{Cu}$ sessile drop at $1130^{\circ} \mathrm{C}$. Flux through bottom surface, impermeable top and sides.

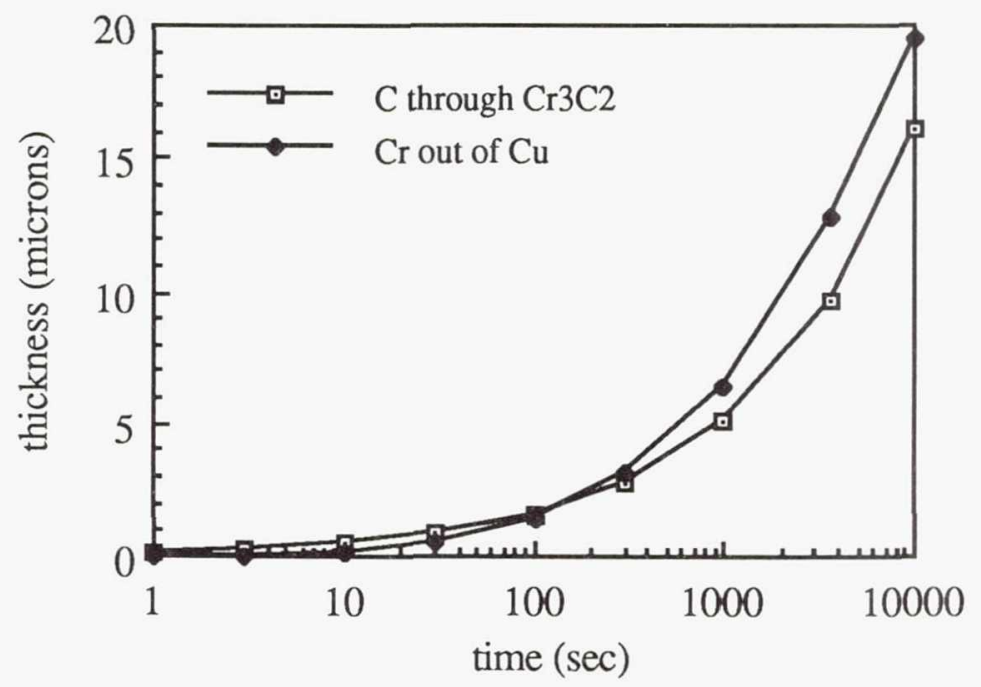

Figure 10. Reaction layer thickness as a function of time at $1130^{\circ} \mathrm{C}$. Controlling growth mechanisms: diffusion of $\mathrm{Cr}$ out of liquid $\mathrm{Cu}$, and diffusion of $\mathrm{C}$ through solid $\mathrm{Cr}_{3} \mathrm{C}_{2}$. 
Implications for Gr/Cu composites

Many favorable properties of Gr fibers are attributed to their surface finish. Because of this, considerable concern has been noted of the possibility of severe degradation of Gr fibers from gross reaction layer formation $[3,4,5]$. Severe damage to the fiber surface could lead to degradation of the overall composite properties. Having observed reaction layers with thicknesses up to $10 \mu \mathrm{m}$ for the sessile drop configuration, it is necessary to calculate the thickness of the reaction layer expected in an actual composite. The amount of the Gr fiber that will be consumed by the reaction can also be estimated.

The thickness of the $\mathrm{Cr}_{3} \mathrm{C}_{2}$ reaction layer that forms in actual $\mathrm{Gr} / \mathrm{Cu}$ composites is much reduced compared with that which forms in the sessile drop tests because of the greatly increased $\mathrm{Gr}$ surface area per volume of $\mathrm{Cu}-\mathrm{Cr}$ alloy. The following expression gives the $\mathrm{Gr}$ surface area per unit volume of composite, $\mathrm{S}_{\mathrm{V}}$ :

$$
\mathrm{S}_{\mathrm{V}}=\frac{2 \mathrm{~V}_{\mathrm{V}}}{\mathrm{r}}
$$

where $V_{V}=$ volume fraction of $\mathrm{Gr}$ fibers in the composite $\mathrm{r}=$ radius of $\mathrm{Gr}$ fibers

For a volume fraction of $0.5,5 \mu \mathrm{m}$ radius $\mathrm{Gr}$ fibers, the $\mathrm{Gr}$ surface area/volume is 200 $\mathrm{mm}^{2} / \mathrm{mm}^{3}$. For a $\mathrm{Cu}-1.22 \mathrm{at} \% \mathrm{Cr}$ alloy matrix there is only enough $\mathrm{Cr}$ available to form a $\mathrm{Cr}_{3} \mathrm{C}_{2}$ reaction layer $36 \mathrm{~nm}$ thick around the Gr fibers, asuming a homogeneous distribution of fibers. If a leaner alloy with $0.12 \mathrm{at} \% \mathrm{Cr}$ were used as the matrix, the maximum reaction layer thickness would be reduced to $1.5 \mathrm{~nm}$.

The atomic volumes of $\mathrm{C}$ in $\mathrm{Gr}$ and $\mathrm{Cr}$ in $\mathrm{Cu}$ are approximately 8.8 and $12 \AA^{3}$, respectively [18]. This implies that a distance equal to about one third of the thickness of the $\mathrm{Cr}_{3} \mathrm{C}_{2}$ reaction layer formed would come from the surface of the Gr fibers; two thirds of its 
thickness would come from the $\mathrm{Cu}-\mathrm{Cr}$ alloy. Therefore, the formation of the reaction layer phase consumes only a limited percentage of the Gr fiber.

The molecular volume of $\mathrm{Cr}_{3} \mathrm{C}_{2}$ based upon a density of $6.68 \mathrm{~g} / \mathrm{cm}^{3}$ is approximately $44.7 \AA^{3}$. There is a reduction in volume of $16.5 \%$ when $\mathrm{C}$ in $\mathrm{Gr}$ and $\mathrm{Cr}$ in $\mathrm{Cu}$ combine to form $\mathrm{Cr}_{3} \mathrm{C}_{2}$. If the reaction layer forms when the $\mathrm{Cu}-\mathrm{Cr}$ alloy matrix is in the solid state, to maintain continuity the fibers and the reaction layer will be put into a state of residual tension [19]. The matrix will be put into a state of pure shear if it is assumed that no outside forces are exerted by one fiber upon another.

\section{CONCLUSIONS}

All four $\mathrm{Cu}-\mathrm{Cr}$ alloys with $\mathrm{Cr}$ contents of 0.61 to 1.22 at\% formed reaction layers with the $\mathrm{Gr}$ substrates when held at $1130^{\circ} \mathrm{C}$ for $3600 \mathrm{~s}$. The initial reaction layer formed was identified by combined EDS, AES and x-ray diffractometry analyses to be $\mathrm{Cr}_{3} \mathrm{C}_{2}$ for the $\mathrm{Cu}$ $0.61 \mathrm{at} \% \mathrm{Cr}$ alloy. The molten $\mathrm{Cu}-\mathrm{Cr}$ alloy sessile drops were found to wet the chromium carbide reaction layer to a contact angle of $\approx 45^{\circ}$ once the layer became continuous.

A thermodynamic analysis of the formation of chromium carbide phases from $\mathrm{Cr}$ dissolved in liquid $\mathrm{Cu}$ and $\mathrm{C}$ in $\mathrm{Gr}$ showed that $\mathrm{Cr}_{3} \mathrm{C}_{2}$ was the most stable of the candidate phases. The $\mathrm{Cr}$ content of liquid $\mathrm{Cu}$ at $1130^{\circ} \mathrm{C}$ would have to be reduced to below $0.078 \mathrm{at} \%$ before the formation of $\mathrm{Cr}_{3} \mathrm{C}_{2}$ would not be favorable. The formation of chromium carbide reaction layers about $10 \mu$ m thick for the $\mathrm{Cu}-\mathrm{Cr}$ alloys with approximately $1 \mathrm{at} \%$, or greater, $\mathrm{Cr}$ was found to be limited by diffusion through the carbide layer.

Because of the large $\mathrm{Gr}$ surface area to volume ratio in realistic $\mathrm{Gr} / \mathrm{Cu}$ composite materials, the extent of reaction layer thickness should be limited to on average a few nanometers by the $\mathrm{Cr}$ content in the $\mathrm{Cu}$ alloy. The formation of a $\mathrm{Cr}_{3} \mathrm{C}_{2}$ reaction layer in the 
solid state will put the $\mathrm{Gr}$ fibers and the reaction layer in a state of residual tension and $\mathrm{Cu}-\mathrm{Cr}$ alloy matrix in a state of pure shear.

\section{ACKNOWLEDGEMENTS}

The authors would like to recognize support from the Defense Advanced Research Projects Agency through a URI Grant and the NASA Lewis Research Center in Cleveland, Ohio, through a NASA Graduate Student Researchers Program Fellowship under Grant no. 50-632. Helpful discussions with Dr. David Ellis and Dr. Hugh Gray of NASA LeRC are greatly appreciated.

\section{REFERENCES}

${ }^{1}$ D.L. McDanels and J.O. Diaz, "Exploratory Feasibility Studies of Graphite Fiber Reinforced Copper Matrix Composites for Space Power Radiator Panels", NASA TM-102328 (1989).

${ }^{2}$ F. Weitzer, K. Remschnig, J. C. Schuster and P.Rogl, "Phase Equilibria and Structural Chemistry in the Ternary Systems M-Si-N and M-B-N", J. Mat. Research, 5 [10] 2152-59 (1990).

${ }^{3}$ D. Mortimer and M. Nicholas, "The Wetting of Carbon by Copper and Copper Alloys", J. Mat. Sci., 5 [2] 149-155 (1970).

${ }^{4}$ M. Nicholas and D. Mortimer, "The Wetting of Carbon by Liquid Metals and Alloys"; pp. 1-3 in proceedings of International Conference on Carbon Fibers, their Composites and Applications, London, February 2-4, 1971.

${ }^{5}$ D. Mortimer and M. Nicholas, "The Wetting of Carbon and Carbides by Copper Alloys", J. Mat. Sci., 8 640-48 (1973). 
${ }^{6}$ L. Murr, "Interfacial Free Energy"; p. 102 in Interfacial Phenomena in Metals and Alloys. Addison-Wesley Publ. Co., Reading, MA, 1974.

7L. Ramqvist, "Wetting of Metallic Carbides by Liquid Copper, Nickel, Cobalt and Iron", Int. J. Pow. Met., 1 [4] 2-21 (1965).

${ }^{8}$ K. Nogi, Y. Osugi and K. Ogino, “A New Method of Wettability Measurement Utilizing a Small Sample and Its Application to Graphite or $\alpha$-SiC and Liquid Cu-Cr Alloy Systems", ISIJ, 30 [1] 64-9 (1990).

${ }^{9}$ Nat. Bur. Stand. (U.S.) Monogr., 21 (1984).

10D.J. Chakrabarti and D.E. Laughlin, Bull. Alloy Phase Diagrams, 5 [1] (1984).

11 J.F. Elliot and M. Gleiser, "Thermochemistry for Steelmaking"; pp. 135-36. Addison-Wesley Publ. Co., Reading, MA, 1960.

${ }^{12}$ H.S. Carslaw and J.C. Jaeger, "Conduction of Heat in Solids"; pp. 119-20. Oxford University Press, New York, 1959.

13P.M. Shurygin and V.D. Shantarin, "Compensation Effects in the Diffusion of Metals in Molten Copper", Zhur. Fiz. Khim., 42 [2] 463-65 (1968).

14P.G. Shewmon, "Diffusion in Solids"; p. 360. McGraw Hill, Inc., New York, 1969.

15 R.J. Fries, J.E. Cummings, C.G. Hoffman and S.A. Daily, "Chemical Diffusion of C in the Group VI-B Metal Carbides", US At. Energy Comm. Report: LA-3795 (1967).

16E.K. Storms, "The Refractory Carbides"; pp. 47-60, 102-121. Academic Press, New York, 1967.

${ }^{17}$ R. Hultgren, P.D. Desai, D.T. Hawkins, M. Gleiser, K.K. Kelley and D.D. Wagman, "Selected Values of Thermodynamic Properties of the Elements"; p. 155. American Society for Metals, Metals Park, Ohio, 1973.

${ }^{18}$ C.S. Barrett and T.B. Massalski, "Structure of Metals"; p. 627. McGraw Hill, Inc., New York, 1966.

${ }^{19}$ S.P. Timoshenko and J.N. Goodier, "Theory of Elasticity"; pp. 68-71. McGraw Hill, Inc., New York, 1970. 


\section{REPORT DOCUMENTATION PAGE}

Public reporting burden for this collection of information is estimated to average 1 hour per response, including the time for reviewing instructions, searching existing data sources, gathering and maintaining the data needed, and completing and reviewing the collection of information. Send comments regarding this burden estimate or any other aspect of this collection of information, including suggestions for reducing this burden, to Washington Headquarters Services, Directorate for information Operations and Reports, 1215 Jefferson Davis Highway, Suite 1204, Arlington, VA 22202-4302, and to the Office of Management and Budget, Paperwork Reduction Project (0704-0188), Washington, DC 20503.

\begin{tabular}{|l|l|l|}
\hline 1. AGENCY USE ONLY (Leave blank) & $\begin{array}{r}\text { 2. REPORT DATE } \\
\text { March } 1992\end{array}$ & $\begin{array}{r}\text { 3. REPORT TYPE AND DATES COVERED } \\
\text { Final Contractor Report }\end{array}$ \\
\hline
\end{tabular}

\section{TITLE AND SUBTITLE}

Reaction Layer Formation at the Graphite/Copper-Chromium Alloy Interface

6. $\operatorname{AUTHOR}(\mathrm{S})$

Sandra M. DeVincent and Gary M. Michal

\section{FUNDING NUMBERS}

G-NCC3-94

\section{PERFORMING ORGANIZATION}

REPORT NUMBER

Case Western Reserve University

Department of Materials Science and Engineering

Cleveland, Ohio 44106

9. SPONSORING/MONITORING AGENCY NAMES(S) AND ADDRESS(ES)

National Aeronautics and Space Administration

Lewis Research Center

Cleveland, Ohio 44135-3191

10. SPONSORING/MONITORING AGENCY REPORT NUMBER

NASA CR-189147

11. SUPPLEMENTARY NOTES

Project Manager, Robert Miner, Materials Division, NASA Lewis Research Center, (216) 433-3270. Prepared for the 1991 TMS Annual Meeting, New Orleans, Louisiana, February 17-21, 1991.

12a. DISTRIBUTION/AVAILABILITY STATEMENT

12b. DISTRIBUTION CODE

Unclassified - Unlimited

Subject Category 26

13. ABSTRACT (Maximum 200 words)

Sessile drop tests were used to obtain information about copper-chromium alloys that suitably wet graphite. Characterizations of graphite/copper-chromium alloy interfaces subjected to elevated temperatures were conducted using scanning electron microscopy, energy dispersive spectroscopy, auger electron spectroscopy and x-ray diffraction analyses. These analyses indicate that during sessile drop tests conducted at $1130{ }^{\circ} \mathrm{C}$ for 1 hour, copper alloys containing greater than 0.98 at $\%$ chromium form continuous reaction layers of approximately $10 \mu \mathrm{m}$ thickness. The reaction layers adhere to the graphite surface. The copper wets the reaction layer to form a contact angle of $60^{\circ}$ or less. X-ray diffraction results indicate that the reaction layer is chromium carbide. The kinetics of reaction layer formation were modelled in terms of bulk diffusion mechanisms. Reaction layer thickness is controlled initially by the diffusion of $\mathrm{Cr}$ out of the $\mathrm{Cu}$ alloy and later by the diffusion of $\mathrm{C}$ through chromium carbide.

14. SUBJECT TERMS

Copper; Graphite; Interface; Reaction layer; Diffusion mechanisms

15. NUMBER OF PAGES

24

16. PRICE CODE

$\mathrm{A} 03$

\begin{tabular}{|c|c|c|}
\hline $\begin{array}{c}\text { 17. SECURITY CLASSIFICATION } \\
\text { OF REPORT } \\
\begin{array}{c}\text { Unclassified } \\
\text { Un }\end{array}\end{array}$ & $\begin{array}{c}\text { 18. SECURITY CLASSIFICATION } \\
\text { OF THIS PAGE } \\
\text { Unclassified }\end{array}$ & $\begin{array}{c}\text { 19. SECURITY CLASSIFICATION } \\
\text { OF ABSTRACT } \\
\text { Unclassified }\end{array}$ \\
\hline
\end{tabular}


National Aeronautics and

Space Administration

Lewis Research Center

Cleveland, Ohio 44135

Otficial Business

Penalty for Private Use $\$ 300$

ADDRESS CORRECTION REQUESTED

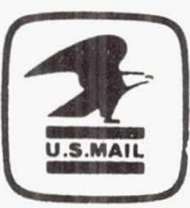

Poslage and Fees Paid Natıonal Aeronautıcs and Space Administration

NASA 451 